\title{
Development of a Scale for Students in Evaluating 2017 Information Technology and Software Curriculum ${ }^{1}$
}

\section{Elif Buğra Kuzu Demir}

PhD. Dokuz Eylül University, İzmir, Turkey, elif.demir@deu.edu.tr

\section{Gülten Feryal Gündüz}

PhD. İstanbul Kültür University, İstanbul, Turkey, gferyal.kucuker@gmail.com

\begin{abstract}
The purpose of this study was to develop a valid and reliable instrument measuring the views of secondary school $5^{\text {th }}$ grade students on the curriculum of 2017 Information Technology and Software (ITS) course. The study was carried out with $5285^{\text {th }}$ grade students (15 for pilot application, 320 for exploratory factor analysis (EFA), 203 for confirmatory factor analysis (CFA) studying in the spring semester of 2017-2018 school year. Implementation of the scale was realized with participants who were determined through the combination of criterion and convenience sampling. In order to determine the content validity and face validity of the scale, expert opinions were obtained, while both EFA and CFA were performed to assess the construct validity of the scale's measures. Analyses revealed one-factor structure which sheltered 30 items, which explained 39.92 percent of the total variance with a high internal consistency coefficient. The CFA on the one-factor structure revealed acceptable fit indices as well. Based on these findings, it could be concluded that the scale is an instrument that produces valid and reliable measures, and that can be used to determine fifth grade students' views on the curriculum evaluation of 2017 ITS course. For further studies, the scale can be implemented to a random sample form the population of $5^{\text {th }}$ grade students to reveal their views on the curriculum and studies can be conducted in order to investigate in terms of different variables.
\end{abstract}

Keywords: curriculum, curriculum of information technologies and software course, secondary school, curriculum evaluation, scale development

\footnotetext{
${ }^{1}$ This study was presented as an oral presentation at the $12^{\text {th }}$ International Computer Education and Instructional Technology Symposium organized by Ege University between 2-4 May 2018

Citation: Kuzu Demir, E. B., \& Gündüz F. G. (2019). Development of a Scale for Students in Evaluating 2017 Information Technology and Software Curriculum. International Journal of Instruction, 12(4), 313-330. https://doi.org/10.29333/iji.2019.12420a
} 


\section{INTRODUCTION}

The rapid development and spread of information technologies (IT) leads to an increase in the need for labor force trained in appropriate and effective use of these technologies. It is expected that the talented labor force is equipped with not only the skills to use existing technologies but also the $21^{\text {st }}$ century skills such as innovation, entrepreneurship, creativity, productivity, critical thinking, problem solving and so forth. At this point, the greatest task in having individuals acquire these skills falls into the schools that prepare them for life and future (Gülbahar \& Kalelioğlu, 2018). Including courses in schools where students can have theoretical and practical knowledge about developing IT at different levels of education ranging from preschool to postgraduate education, provides digital competencies for students who are members of the society. Through these competencies, they will be able to use IT effectively and fluently in the society they live in; moreover, they will be able to transform their society for the better, such as a society that capable of producing these technologies. One of the most important actors contributing to the realization of this transformation process in our country is the IT courses in the education programs of the schools within the Ministry of National Education (MNE). One of these IT courses is the Information Technology and Software (ITS) course, which is taught in primary and secondary schools. 2017 ITS course curriculum was presented to public debate by the MNE on January 13, 2017 and after taking into consideration the opinions of the relevant persons, institutions and organizations from all walks of life it was published in the Publications Journal dated 17 July 2017 (MNE, 2017b).

Accordingly, it was decided that the new curriculum of the ITS course will be applied gradually at all grade levels starting from the $5^{\text {th }}$ grade in the 2017-2018 academic year. The overall objective of the ITS course, which focuses on the idea of developing not only mental skills, but also emotional and social skills of students, is to guide students on the way of becoming a good digital citizen. In addition, one of the general objectives of the program is to ensure that students use advanced information and communication technologies to serve the development plan of the country economy based on production. During the development of ITS course curriculum, Turkish Qualifications Framework (TQF) was taken into consideration. (Gündüz \& Kuzu Demir, 2018; MNE, 2017a). The TQF is a national qualifications framework that complies with the European Qualifications Framework (European Parliament and the Council of Europe, 2008) and demonstrates all qualifications principles acquired through vocational, general and academic education and training programs and other learning pathways in all stages of education (Vocational Qualifications Institution, 2015). In the TQF, eight key competences that students will need in their social and academic lives are identified. These key competences are communication in mother tongue, communication in foreign languages, mathematical competence, basic competences in science / technology, digital competence, learning to learn, social and citizenship competence, taking initiative and entrepreneurship perception and cultural awareness and expression competences. It is ensured that these competencies are related to the learning skills that are aimed to be acquired in the ITS curriculum. In the curriculum of the ITS course taught in primary and secondary schools, unit-based approach is taken as the basis. There are five basic 
units in the new program, which is focusing on the development of students' computing skills, logical inquiry, programming and designing algorithms as well as the ability to use IT effectively. These units are IT, ethics and security, communication, research and collaboration, product creation, problem solving and programming (MNE, 2017a).

While teaching the unit contents, it is emphasized that appropriate teaching approaches should be used to make students active, the selection of learning environments and materials should be suitable for the purpose of teaching, and the assessment and evaluation practices of learning-teaching process should be coordinated and supporting each other. In this respect, it is stated that, the students should be followed up and guided, their learning difficulties should be identified and eliminated, an assessment and evaluation approach should be adopted to provide continuous feedback to support meaningful and permanent learning in students (MNE, 2017b). As mentioned above, since there appears the need for trained labor force in the efficient use of these technologies, and in parallel with this reality, causes the need for continuous updating and renewal of the curriculum of these IT courses taught in different stages of education. Additionally, regular evaluation of curriculum particularly by in-class partners, contributes greatly to program developers and program development studies of the MNE by providing data from the primary source based on the principal practitioners' perspective (Kocabatmaz, 2011). In this context, it is aimed to develop a scale, which can be used to determine the opinions of the students among the in-class partners. Determination of the students' views will enable the experts who develop the program and / or the managers / financiers evaluate the 2017 ITS curriculum from a student perspective. It is thought that the scale to be used in the evaluation of the 2017 ITS curriculum in the study will be beneficial in terms of determining the strengths and weaknesses of the curriculum according to the students' views, improving its weaknesses and eliminating the deficiencies of the program. When the literature is examined, it is seen that there are few studies about the evaluation of the 2017 curriculum (Bilişim Teknolojileri Eğitimcileri Derneği [Association of ICT Educators], 2017; Gülbahar \& Kalelioğlu, 2018; Gündüz \& Kuzu Demir, 2018; Karaman \& KAraman, 2019; Mercimek \& İlic, 2017). The small number of these studies conducted for the purpose of evaluating the 2017 curriculum is designed with the qualitative research methods using document analysis or teacher opinions as data collection tools. In other words, no study has been found in which the views of the students who directly experienced the curriculum. And also, the lack of a study designed with quantitative research methods using such as scale development or survey model carried out in a large sample for the purpose of evaluating the curriculum increases the importance of this study. The general aim of the study is to develop an assessment tool for the purpose of determining the opinions of $5^{\text {th }}$ grade students in the 2017 ITS course curriculum. Besides, it is aimed that this measurement tool can be used as a valid and reliable scale by the researchers in evaluating the 2017 ITS curriculum according to the student views.

\section{METHOD}

In this section, the study group of the research and the procedure used during the scale development were explained respectively. 


\section{Study Group}

The participants were selected simultaneously from the convenience sampling and the criteria sampling which are two of the purposive sampling methods. Criterion sampling is the determination of situations that meet a predetermined set of criteria (Y1ldirim \& Şimşek, 2008). The criteria determined are that the students being in the $5^{\text {th }}$ grade of the school and their ITS courses are carried out according to the 2017 ITS course curriculum. In this study, convenient sampling enabling the researchers choose participants from easy to reach, suitable for research and voluntary individuals was also used in the selection of schools (Gravetter \& Forzano, 2012). The schools were selected among the schools which meet the criteria mentioned above and where the researchers could easily reach. In this context, the participants are the $5^{\text {th }}$ grade students from the schools one of which is from the European part of Istanbul, another is from the city center of İzmir and the others from 3 different schools in Sakarya. Classes of these $5^{\text {th }}$ grade students were also selected with the convenient sampling method and the students in these classes formed the study groups of the researches. Table 1 shows the numbers of the school $5^{\text {th }}$ grade students according to their gender.

Table 1

Demographic Characteristics of the Students Participating in the Research

\begin{tabular}{lllll}
\hline \multirow{2}{*}{$\begin{array}{l}\text { Type of } \\
\text { Analysis }\end{array}$} & \multirow{2}{*}{ Gender } & Predicted Quantity & Evaluated Quantity & Predicted Quantity \\
\cline { 3 - 5 } & & F & $\%$ & F \\
\hline Exploratory & Female & 153 & 46,64 & 153 \\
Factor & Male & 175 & 53,36 & 175 \\
Analysis & Total & 328 & 100 & 328 \\
\hline Confirmatory & Female & 97 & 45,12 & 97 \\
Factor & Male & 118 & 54,88 & 118 \\
Analysis & Total & 215 & 100 & 215 \\
\hline
\end{tabular}

Although the sample size is important in obtaining reliable results in exploratory factor analysis (EFA) during scale development process, there are different suggestions about how much this sample size should be. Some researchers regard the number of items to decide on sample size; the others consider factor loadings and factor structure or types of validity and reliability analysis. Catell (1978) states that for each item in the assessment tool, the number of participants should be between 3 and 6 ; whereas Gorsuch (1983) states that this value should be at least 5. According to some authors, there is also a correlation between sample size and factor loading value. Kim-Yin (2004) proposes specific sample sizes so that an item can remain in scale. Accordingly, the sample size should be at least 200 for an item with a factor loading of 0.40 (cited in Çokluk \& Şekercioğlu, 2012). Comrey and Lee (1992) states respectively that a sample of 100 participants is insufficient, 200 is average, 300 is good, 500 is very good and 1000 participants is excellent. In the literature, it is stated by many experts that the most favorable number for the EFA is 300 (Field, 2009; Kass \& Tinsley, 1979; Tabacnick \& Fidell, 2000). In this study, considering the literature, factor loadings were determined as .40 in factor analyses and in this respect, the sample size was ensured to be more than 200 and the number of participants to be more than 6 for each item number. For the EFA, data were collected from 328 students including 175 male and 153 female. Eight 
students were not evaluated due to incorrect or incomplete filling of the measuring instrument. Of the evaluated 320 pieces of data; 170 of them were obtained from male and 150 of them from female students. For CFA, the related literature states that the sample size should be at least 100 (Brown, 2006; Marsh \& Hau; 1999; Sapnas \& Zeller, 2002). As it can be seen in Table 1, CFA was planned to be carried out with 215 students; however, it was carried out with the data obtained 203 students (111 male, 92 female) due to missing or incorrect filling of 12 students.

\section{Scale Development and Procedures}

Within the scope of the study, "2017 ITS Curriculum Evaluation Student Scale" was developed. The aim of the scale is to reveal the opinions of 5th grade students of secondary school about the ITS course which was implemented in 2017. In order to determine the items of the draft form, literature regarding scale development or adaption for evaluation of a course, preferably ITS course, questionnaire studies and 2017 school 5 th grade ITS course curriculum were examined. In addition to the data obtained from the literature, the experiences of the researchers were also used in the creation of the item pool. One of the researchers is working as an ITS teacher in a secondary school and giving the ITS courses of the 5th and 6th grades in a secondary school. The other researcher is a faculty member of the Department of Computer Education and Instructional Technology (CEIT) at a university. In this context, the opinions of the researchers regarding the 5th grade ITS courses in which they teach or observe according to the 2017 ITS curriculum were also taken into consideration. The program evaluation models in the literature were also taken into consideration while developing the item pool. Primarily, the draft scale form was examined in terms of scope validity. The opinions of 10 experts were obtained, five of whom are from the field of CEIT, two experts from the field of program evaluation, two from the field of assessment and evaluation, and one from the Turkish language. These experts evaluated the assessment tool in terms of the suitability of the Turkish language, the characteristics of the group to be applied and the content to be measured. According to the expert opinions, necessary corrections made in terms of subject-verity harmonization, simplicity of expressions and compliance with cognitive levels of 5 th grade students and 8 items were removed from the draft form. Opinions of experts were compared in terms of similarities and differences and joint decisions were taken.

After getting expert reviews and having the final form in 5-point Likert type, the 36-item questionnaire was applied to fifteen 5th grade school students ( 9 male and 6 female) who also had similar characteristics with the participants for pilot application. With the pilot application, it was aimed to determine whether the students had difficulty in understanding draft scale form. It was observed that there were no items that were difficult to understand by the students. Table 2 provides information on the relevant literature used as a basis for writing the scale items: 
Table 2

The Basis for the Scale Items

\begin{tabular}{|c|c|c|}
\hline No & Items & Reference \\
\hline 1 & The objectives of our course are clear and understandable. & MNE (2017)- ITS Program \\
\hline 2 & $\begin{array}{l}\text { The objectives and content of our course are compatible with each } \\
\text { other. }\end{array}$ & Uzgur and Aykaç, 2016; Aközbek, 2008; \\
\hline 3 & The objectives of our course are at the level that I can achieve. & Uzgur and Aykaç, 2016; Tanataş, 2010 \\
\hline 4 & The activities of our course can be carried out unplugged & MNE (2017)- ITS Program \\
\hline 5 & $\begin{array}{l}\text { The lecture of that day's course subject is completed within a class } \\
\text { hour. }\end{array}$ & $\begin{array}{l}\text { Çengel, 2007; Uzgur and Aykaç, 2016; } \\
\text { Akbıyık and Seferoğlu, 2012; Aközbek, 2008 }\end{array}$ \\
\hline 6 & $\begin{array}{l}\text { The course materials (presentations, videos, activity papers) make me } \\
\text { learn easier. }\end{array}$ & $\begin{array}{l}\text { MNE (2017)- ITS Program; In-class } \\
\text { researcher experiences }\end{array}$ \\
\hline 7 & The content of the course materials is at a level that I can understand. & Uzgur andAykaç, 2016 \\
\hline 8 & The course materials arouse my interest in the course & $\begin{array}{l}\text { Aközbek, 2008; Çengel, 2007; Kural Er and } \\
\text { Güven, 2008; Tanataş, } 2010\end{array}$ \\
\hline 9 & The activities in the student workbook are at the level that I can do. & Tanataş, 2010; In-class researcher experiences \\
\hline 10 & The course materials contain information that I can use in my daily life. & $\begin{array}{l}\text { Uzgur and Aykaç, 2016; Kural Er and Güven, } \\
\text { 2008; Tanataş, } 2010\end{array}$ \\
\hline 11 & $\begin{array}{l}\text { The topics are related to the information technologies (IT) (laptops, } \\
\text { tablet computers, smartphones, internet ...) we are currently using. }\end{array}$ & $\begin{array}{l}\text { Uzgur and Aykaç, 2016; Kural Er and Güven, } \\
\text { 2008; Tanataş, } 2010\end{array}$ \\
\hline 12 & $\begin{array}{l}\text { What I have learned in the course develops my skills in expressing } \\
\text { myself in my mother tongue. }\end{array}$ & MNE (2017)- ITS Program \\
\hline 13 & $\begin{array}{l}\text { What I have learned in the course improves my ability to express } \\
\text { myself in a foreign language. }\end{array}$ & MNE (2017)- ITS Program \\
\hline 14 & $\begin{array}{l}\text { What I have learned in the course improves my mathematics lesson } \\
\text { skills. }\end{array}$ & MNE (2017)- ITS Program \\
\hline 15 & $\begin{array}{l}\text { What I have learned in the course improves my science and technology } \\
\text { lesson skills. }\end{array}$ & MNE (2017)- ITS Program \\
\hline 16 & $\begin{array}{l}\text { What I have learned in the course develops my skills on how to learn } \\
\text { new knowledge. }\end{array}$ & MNE (2017)- ITS Program \\
\hline 17 & $\begin{array}{l}\text { What I have learned in the course improves my social studies lesson } \\
\text { skills. }\end{array}$ & MNE (2017)- ITS Program \\
\hline 18 & $\begin{array}{l}\text { What I have learned in the course improves my ability to decide on any } \\
\text { subject that I may encounter in my daily life. }\end{array}$ & MNE (2017)- ITS Program \\
\hline 19 & What I have learned in the course improves my creativity skills. & MNE (2017)- ITS Program \\
\hline 20 & $\begin{array}{l}\text { What I have learned in the course develops my (entrepreneurship) skills } \\
\text { in developing a new product. }\end{array}$ & $\begin{array}{l}\text { Akbiyik and Seferoğlu, 2012; MNE (2017)- } \\
\text { ITS Program }\end{array}$ \\
\hline 21 & The course activities improve my self-directed learning skills. & $\begin{array}{l}\text { Akbıyık and Seferoğlu, 2012; Aközbek, 2008; } \\
\text { MNE (2017)- ITS Program }\end{array}$ \\
\hline 22 & $\begin{array}{l}\text { The course activities develop my group-based (collaborative) learning } \\
\text { skills. }\end{array}$ & $\begin{array}{l}\text { Akbıyı and Seferoğlu, 2012; Aközbek, 2008; } \\
\text { MNE (2017) }\end{array}$ \\
\hline 23 & The course activities are related to my daily life. & MNE (2017)- ITS Program \\
\hline 24 & $\begin{array}{l}\text { The course activities provide me participate actively in the learning } \\
\text { process. }\end{array}$ & Uzgur and Aykaç, 2016; Aközbek, 2008; \\
\hline 25 & $\begin{array}{l}\text { What I have learned in the course provides me to use IT effectively and } \\
\text { correctly. }\end{array}$ & In-class researcher experiences \\
\hline 26 & $\begin{array}{l}\text { What I have learned in the course allows me to reason about how to } \\
\text { solve the problem when I encounter one. }\end{array}$ & Akbıyık and Seferoğlu, 2012 \\
\hline 27 & $\begin{array}{l}\text { What I have learned in the course improves my ability to think logically } \\
\text { when I need to decide on a topic. }\end{array}$ & MNE (2017)- ITS Program \\
\hline 28 & What I have learned in the course provides me to learn IT willingly. & Aközbek, 2008; Çengel, 2007 \\
\hline 29 & $\begin{array}{l}\text { What I have learned in the course enables me to use IT in accordance } \\
\text { with ethical values. }\end{array}$ & MNE (2017)- ITS Program \\
\hline 30 & $\begin{array}{l}\text { What I have learned in the course allows me to verbally express the } \\
\text { procedures I need to do while writing a computer program. }\end{array}$ & MNE (2017)- ITS Program \\
\hline 31 & $\begin{array}{l}\text { What I have learned in the course provides me to use visual expressions } \\
\text { (schemes, arrows, etc.) step-by-step while writing a computer program }\end{array}$ & MNE (2017)- ITS Program \\
\hline 32 & $\begin{array}{l}\text { What I have learned in the course provides me to use the IT by paying } \\
\text { attention to the features that a good digital citizen should have. }\end{array}$ & $\begin{array}{l}\text { MNE (2017)- ITS Progr } \\
\text { researcher experiences }\end{array}$ \\
\hline 33 & $\begin{array}{l}\text { What I have learned in the course provides me to use IT in a way that } \\
\text { will not harm my health. }\end{array}$ & $\begin{array}{lcr}\text { MNE } \quad(2017)- & \text { ITS } \\
\text { In-class researcher experiences }\end{array}$ \\
\hline 34 & What I have learned in the course improves the skills of using IT safely. & MNE (2017)- ITS Program \\
\hline 35 & $\begin{array}{l}\text { What I have learned in the course improves my research skills using the } \\
\text { internet. }\end{array}$ & MNE (2017)- ITS Program \\
\hline 36 & What I have learned in the course develops my programming skills. & MNE (2017)- ITS Program \\
\hline
\end{tabular}

International Journal of Instruction, October $2019 \bullet$ Vol.12, No.4 
Scale items were prepared in 5-point likert type format. The rating ranges from 1 to 5 , respectively meaning "Strongly disagree", "Disagree", "Neither agree nor disagree", "Agree", and "Strongly agree".

\section{FINDINGS}

\section{Construct Validity}

After the EFA, which is for determining the factor pattern for the assessment tool, it is desirable to perform the CFA of the model as well. In this study, EFA was primarily performed, then CFA was performed by LISREL and then the factor structure was confirmed following the testing of determining latent and observed variable relationships (Raykov \& Marcoulides, 2006).

\section{EFA Results}

In order to examine the formation of data obtained during the scale development process and to eliminate the items that do not work, Principal component analysis (PCA) was used within the scope of EFA. Çokluk et al. (2012) describe the PCA as a solution for the researcher who wants to collect a large number of variables by reducing them under a smaller number of components. Before the EFA was performed, the data set was adapted to the analysis. Using the data obtained, firstly the scales, whose items were given the same score, and which were thought to be not filled out sincerely, were removed. Whether the data show normal distribution and outliers were determined by using Z-scores. For each item, Z-score which is not between -3 and +3 , were not taken into consideration (Büyüköztürk, 2010). Based on these criteria eight questionnaires were excluded from the research. The suitability of the data was examined with the Kaiser-Mayer-Olkin (KMO) coefficient and Barlett's Sphericity test. Pallant (2005) suggests a KMO value of at least .60 for a good factor analysis. The Bartlett test; however, is based on the hypothesis that the factor analysis for variables is appropriate when the correlation between the variables is different from 1. In factor analysis, a high correlation is expected between variables (Büyüköztürk, 2010). The results obtained from KMO and Barlett test are shown in Table 3.

Table 3

KMO and Bartlett Test Results

\begin{tabular}{lll}
\hline Kaiser-Meyer-Olkin Statistic & &, 947 \\
\hline Bartlett's test of Sphericity & Chi-Square (Approximately) & 4975.071 \\
& Degrees of Freedom & 435 \\
& Significance Level &, 000 \\
\hline
\end{tabular}

As a result of the test, the obtained KMO value of 0.947 indicates that the data set is suitable for factor analyses and an obtained significant $\mathrm{p}$-value $(\mathrm{p}<.001)$ according to the Barlett test shows that there is a high correlation between the variables. Accordingly, it can be said that the sample size is suitable for the principal component analysis. As seen in Table 4, based on the results of the principal component analysis, 36 items are grouped under seven factors with eigenvalues of more than 1. 
Table 4

Factor Eigenvalues and Percentage of Extracted Variance Obtained in the First Analysis

\begin{tabular}{llll}
\hline Factors & Factor eigenvalues & Extracted Variance & Cumulative Variance \\
\hline 1 & 12,389 & 34,414 & 34,414 \\
2 & 2,600 & 7,222 & 41,636 \\
3 & 1,333 & 3,704 & 45,340 \\
4 & 1,184 & 3,288 & 48,628 \\
5 & 1,107 & 3,076 & 51,704 \\
6 & 1,056 & 2,935 & 54,639 \\
7 & 1,002 & 2,783 & 57,422 \\
\hline
\end{tabular}

The distribution of items according to these seven factors and the results of scree plot were examined; however, it was found that the seven-factor structure did not constitute a meaningful structure in determining the views of the students on the evaluation of the ITS curriculum. After the results obtained from principal components analysis, the scree plot obtained for the draft scale is shown in Figure 1.

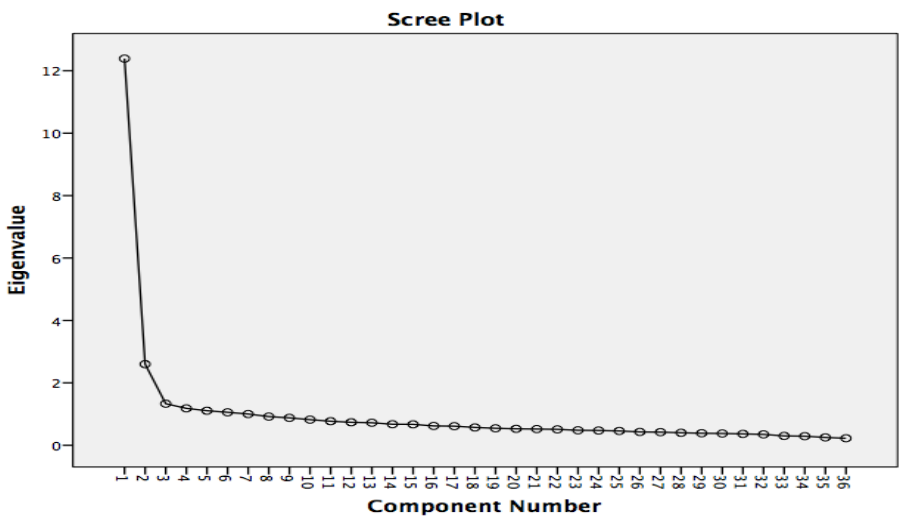

Figure 1

Scree Plot

First, the two-factor structure was examined but it was observed that the distribution of the items in the scale was not consistent with the theoretical dimension. Therefore, taken into consideration the theoretical dimension, single-factor structure was accepted by the researchers. Table 5 shows the factor eigenvalue and extracted variance of the single factor structure:

Table 5

Factor Eigenvalues and Percentage of Extracted Variance Obtained in Single Factor Structure

\begin{tabular}{llll}
\hline Factors & Factor eigenvalue & Extracted variance & Cumulative variance \\
\hline 1 & 11,975 & 39,917 & 39,917 \\
\hline
\end{tabular}

As seen in Table 5, the variance extracted in single factor structure is $39,917 \%$. According to the literature, $30 \%$ or more of the variance explained in a single-factor pattern is regarded as sufficient (Çokluk et al., 2012). When deciding to keep items in 
the draft scale, it was noted that the item factor loading was higher than 0.40 (Fernandez, 2011; Field, 2009; Pallant, 2005; Worthington \& Whittaker, 2006) and a difference of at least 0.10 between the loadings of two factors was also noted if an item was included in more than one factor (Büyüköztürk, 2010). Kim-Yin (2004) also suggests specific sample sizes to decide whether an item should remain in scale. Accordingly, the sample size for an item with a factor loading of 0.30 is at least 350 and for a substance with a factor loading of 0.40 , the sample size should be at least 200 . Items 4, 11 and 13, which are in the original scale consisting of 36 items, were removed from the scale as they were less than .40 in factor loadings; and items 14, 15 and 17, which were also in the original scale, were excluded due to their overlap. The remaining 30 items were included in the new scale and were renumbered between 1 and 30. The results of EFA and factor loadings related to the validity study of the scale are shown in Table 6.

Table 6

EFA and Factor Loading Results of the Scale*

\begin{tabular}{llllll}
\hline Item No & Factor Loadings & Item No & Factor Loadings & Item No & Factor Loadings \\
\hline 1 & .733 & 11 & .655 & 21 & .591 \\
2 & .732 & 12 & .653 & 22 & .581 \\
3 & .720 & 13 & .649 & 23 & .569 \\
4 & .714 & 14 & .634 & 24 & .565 \\
5 & .709 & 15 & .618 & 25 & .565 \\
6 & .699 & 16 & .617 & 26 & .563 \\
7 & .693 & 17 & .614 & 27 & .560 \\
8 & .688 & 18 & .605 & 28 & .557 \\
9 & .670 & 19 & .599 & 29 & .530 \\
10 & .661 & 20 & .595 & 30 & .526 \\
\hline
\end{tabular}

*The scale items were reordered according to their factor loadings.

As shown in Table 6, as the result of the validity study, it was determined that the item loadings were between 0.526 and 0.733 . In the developed scale, a single factor structure was obtained. Total variance extracted by single factor was $39,917 \%$.

\section{CFA Results}

The model which was determined according to the results of EFA, was tested with CFA. For CFA, data were recollected from a sample showing similar characteristics (Worthington and Whittaker, 2006). For this reason, data were collected from a sample group of 215 students who had similar characteristics with the sample selected for EFA to verify the construct validity of the scale. Twelve of these students were not included in the evaluation because of incorrect or incomplete filling of the assessment tool. Scale data consisting of single factor and 30 items were converted to LISREL data and CFA was performed. Table7 shows the fit values obtained in the CFA analysis. The chisquare statistics given in Table 7 is a technique testing the hypothesis that the covariance structures of observed variables and the model is compatible (Özdamar, 2002). Chisquare statistics is indicated as a lack of index fit. However, since chi-square statistics is an aggregate statistic and the value increases along with the number of variables, chisquare / degree of freedom is utilized. If this value is less than 5, the model has a good 
fit and if it is smaller than 3 it is accepted that the model has a very good fit (Byrne, 1998). Accordingly, when the Chi-square / Degree of Freedom ratio is analyzed for the first analysis, it can be said that the model has a very good fit.

Table 7

The Results Obtained Before and After the Modification for CFA

\begin{tabular}{llll}
\hline Fit value & Good fit & Sample Value & Reference \\
\hline Chi-Square (Fit test) $\chi 2$ & $0 \leq \chi 2 \leq 2.5 \mathrm{df}$ & 1192.61 & Kline (2015) \\
Chi-Square/SD $\chi 2 / \mathrm{df}$ & $0 \leq \chi 2 / \mathrm{df} \leq 3$ & 2,94 & Byrne (1998) \\
RMSEA & $0 \leq \mathrm{RMSEA} \leq 0.08$ & 0.098 & Sümer $(2000)$ \\
GFI & $0.90 \leq \mathrm{GFI} \leq 1.00$ & 0.72 & Hooper et al. (2008) \\
AGFI & $0.90 \leq \mathrm{AGFI} \leq 1.00$ & 0.68 & $\begin{array}{l}\text { Hooper et al. (2008); } \\
\text { CFI }\end{array}$ \\
& $0.90 \leq \mathrm{CFI} \leq 1.00$ & 0.91 & $\begin{array}{l}\text { Tümer (2000) } \\
\text { Tabachnick \& Fidell }\end{array}$ \\
SRMR & & & $(2013)$ \\
NNFI & $0 \leq \mathrm{SRMR} \leq 0.08$ & 0.076 & Brown (2006) \\
& $0.90 \leq \mathrm{NNFI} \leq 1.00$ & 0.91 & Thompson $(2004)$
\end{tabular}

Note: Chi-square $(\chi 2)$ : 1188,53; df:548

As shown in Table 7, the RMSEA value was found to be .098. According to the literature, RMSEA index value between 0 and.08 shows good fit (Sumer, 2000); the fact that it is smaller than .10 indicates poor fit (Tabachnick \& Fidell, 2013). For this analysis, it can be said that the fit index is poor. At this stage, in the literature, it is recommended to examine other fit indexes and modification suggestions (Çokluk et al., 2012). GFI (.72) and AGFI (.68) values obtained are also found to correspond poor fit according to the literature (Hooper et al., 2008; Sümer, 2000). However, this fit index does not mean a negative decision about the model. Other fit indexes should also be examined. The SRMR value below .05 corresponds to perfect fit, below .08, to good fit (Brown, 2006), and below .10 correspond to poor fit. In this context, it can be stated that the SRMR obtained from the analysis corresponds to good fit. Finally, NNFI value above .91 corresponds to good fit (Sumer, 2000). Standardized factor loading values obtained from CFA, $\mathrm{t}$ values indicating the statistical significance level of the relationships and values related to the square of the multiple correlation which can be considered as validity indicator (R2) are given in Table 8. 
Table 8

Item Statistics on CFA Findings

\begin{tabular}{lllll}
\hline Item & T & Factor Loading & Error Variance & R2 \\
\hline M1 & 9,41 & 0,61 & 0,63 & 0,37 \\
M3 & 8,19 & 0,55 & 0,70 & 0,30 \\
M4 & 9,31 & 0,61 & 0,63 & 0,37 \\
M5 & 5,83 & 0,40 & 0,84 & 0,16 \\
M6 & 8,70 & 0,57 & 0,67 & 0,33 \\
M7 & 8,83 & 0,58 & 0,66 & 0,34 \\
M8 & 7,19 & 0,49 & 0,76 & 0,24 \\
M9 & 9,97 & 0,41 & 0,83 & 0,17 \\
M10 & 5,90 & 0,41 & 0,83 & 0,17 \\
M11 & 8,45 & 0,56 & 0,69 & 0,31 \\
M12 & 7,14 & 0,48 & 0,77 & 0,23 \\
M13 & 9,01 & 0,59 & 0,65 & 0,35 \\
M14 & 8,41 & 0,56 & 0,69 & 0,31 \\
M15 & 7,01 & 0,48 & 0,77 & 0,23 \\
M16 & 7,47 & 0,50 & 0,75 & 0,25 \\
M17 & 8,11 & 0,54 & 0,71 & 0,29 \\
M18 & 9,61 & 0,45 & 0,80 & 0,20 \\
M19 & 9,98 & 0,64 & 0,59 & 0,41 \\
M20 & 81,09 & 0,60 & 0,52 & 0,48 \\
M21 & 8,50 & 0,59 & 0,65 & 0,35 \\
M22 & 11,51 & 0,56 & 0,68 & 0,32 \\
M23 & 11,48 & 0,71 & 0,49 & 0,51 \\
M24 & 11,50 & 0,71 & 0,49 & 0,51 \\
M25 & 8,89 & 0,58 & 0,49 & 0,51 \\
M26 & 10,99 & 0,67 & 0,66 & 0,34 \\
M27 & 9,94 & 0,60 & 0,55 & 0,45 \\
M28 & 11,78 & 0,73 & 0,62 & 0,38 \\
M29 & 9,85 & 0,63 & 0,47 & 0,53 \\
M30 & 10,07 & 0,65 & 0,60 & 0,40 \\
Int & 0,58 & 0,42 \\
\hline
\end{tabular}

Internal consistency coefficient of the scale: $(\alpha=.94)$

Many studies in the literature emphasize that the t value of any item in the scale should be equal to or greater than 1.96 and the error variance should be less than 90 (Kline, 2015; Raykov \& Marcoulides, 2006; Tabachnick \& Fidell, 2013). When the values in Table 8 are examined, it is seen that the factor loadings, $t$ and $R^{2}$ values are significant at .05 level. Harrington (2009) states that in CFA, factor loading values of .71 and above are excellent, values between .70 - .63 are very good, values between $.62-.55$ are good, and values between $.54-.45$. are decent, and values between $.44-.32$ are poor. As shown in Table 8 factor loadings vary between .40 and .71 . These values indicate that all of the factor loadings obtained in confirmatory factor analysis are acceptable and the majority are good. When the $\mathrm{R}^{2}$ values are examined, it is observed that the amount of variance extract in the items varies between .17 and .51 . The error variances of the items vary between .47 and .84 . According to Kline (2015), the error variance for an item should not exceed .90. It is seen that item error variances of the scale are also below this 
value. In the CFA results, no modification of the items was required. Many of the model's fit values (except for RMSEA, GFI and AGFI) are in good fit range in compliance the different sources in the literature (Brown, 2006; Byrne, 1998; Kline, 2011; Sümer, 2000; Tabachnick \& Fidell, 2013; Thompson, 2004). The connection diagram showing the standard coefficients for the model is presented in Figure 2.

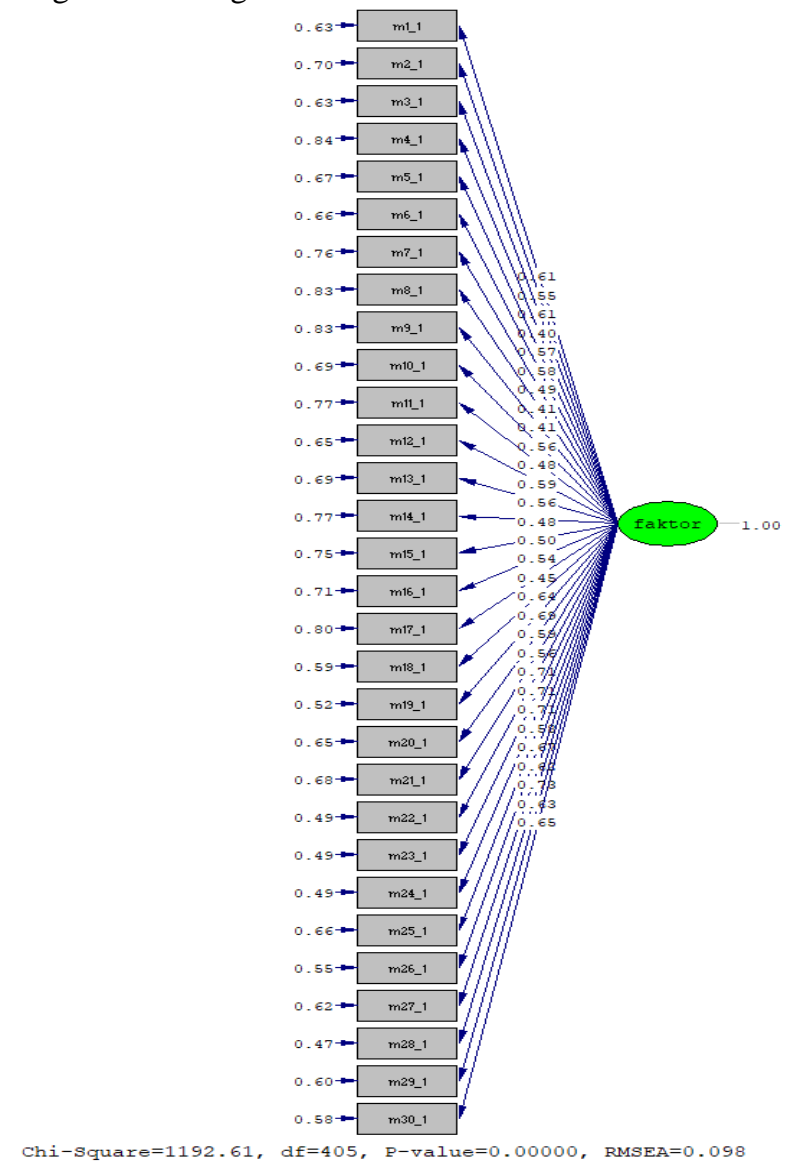

Figure 2

CFA Connection Diagram for the Scale

Cronbach Alpha coefficient was used to determine the internal consistency of the scale. The internal consistency coefficient of the scale was Cronbach's alpha value of 0.94 . The alpha value between 0.80 and 1 is considered to be a high degree of reliability in univariate scales (Ural \& K1lıç, 2013). As a result of the analyses described above, it was decided that the "2017 ITS Curriculum Evaluation Student Scale" which is composed of 30 items and a single factor is a valid and reliable scale that can be used to determine the student opinions about the evaluation of the 2017 ITS course curriculum. 


\section{DISCUSSION AND CONCLUSION}

In 2017, with respect to the innovations and developments in the teaching and learning approaches, MNE made a comprehensive arrangement and renewed its 51 of the consisting curriculum of primary and secondary schools in order to meet the requirements of modern age and the needs of the individual and the society (Board of Education, 2017). It was aimed to conduct preliminary evaluation studies on the renewed draft programs and to share them with the public through MNE Curriculum Monitoring and Evaluation System before the relevant programs were implemented. However, the program evaluation process is a cyclical process that involves the continuous renewal and reorganization of the curriculum from the development of a curriculum to the abolition of the program (Demirtaş, 2017). This process requires the collection, processing and interpretation of data from the stakeholders continuously and repeatedly in order to eliminate the existing deficiencies and errors in the curriculum. In this context, the aim of this study is to develop a valid and reliable measurement tool in order to get the opinions of the students, who are one of the most important stakeholders in the evaluation of the revised ITS curriculum in 2017. The study was carried out with 523 school $5^{\text {th }}$ grade students who studied the ITS course in the spring semester of 20172018 academic year with the renewed curriculum. In this study, the 2017 ITS Course Curriculum Evaluation Student Scale, which consists of 30 items and has a single factor structure, was developed and verified in order to determine the opinions of the school $5^{\text {th }}$ grade students about the 2017 ITS course curriculum. The developed scale extracts a single factor structure with a percentage of $39,917 \%$ of the total variance. Besides, the factor loadings of the items in the scale were between .53 and .73 in EFA; and .40 and .71 in CFA. Fit indices in the CFA conducted to confirm the structure of the scale were calculated as RMSEA $=0.098 ; \mathrm{AGFI}=0.68 ; \mathrm{GFI}=0.72 ; \mathrm{SRM}=0.076 ; \mathrm{NNF} \mathrm{t}=0.91$; $\mathrm{CFU}=0.91 ; \chi^{2} / \mathrm{df}=2.94$. The findings obtained from the EFA and CFA show that the 2017 ITS Course Curriculum Evaluation Student Scale is a valid and reliable scale that can be used to determine the student opinion on the evaluation of the 2017 ITS course curriculum.

Since there is only one scale development study (Karal, Reisoğlu, \& Günaydın, 2010) found in the literature relating to curriculum evaluation of ITS Courses, the results of the present study cannot be discussed immensely and properly. Karal and his colleagues developed a scale by conducting only EFA which had a four-factor structure explaining 67.02 percent of the total variance with a moderate internal consistency coefficient $(\alpha=.87)$, which sheltered 24 items. The factors revealed in the process are general specifications, learning outcome, content and evaluation. In this sense it can be said that both Karal and his colleagues study and this present study offers a valid and reliable scale for evaluating the curriculum of ITS course. But it also should be said that the latter study offers more recent scale related to the advances in the curriculum of ITS course in 2017. Other studies conducted for evaluating the curriculum of ITS courses were designed more often with a case study or a mixed methods design using both surveys and semi-structured interviews (BTE Derneği, 2017; Çelebi Uzgur \& Aykaç, 2016; Durdukoca \& Arıbaş, 2011; Erçetin \& Durak, 2017; Kabakçı, Kurt \& Yııldırım, 2008; Karal, Reisoğlu, \& Günaydın, 2010; Sert, 2007). The researchers also used 
qualitative and quantitative research methodologies solely implementing questionnaires including both close/open-ended questions; (Akbıyık \& Seferoğlu, 2012, Gülcü, Aydın, \& Aydın, 2013) in the former, semi-structured interviews (Seferoğlu, 2007) and document analysis (Barut \& Kuzu, 2017; Demirer \& Sak, 2015; Mercimek \& İliç, 2017; Karaman \& Karaman, 2019) in the latter research methodology, which unfortunately the fit indices of the present study cannot be discussed.

The 2017-2018 school year was the first year in which the new curriculum of the ITS course was taught in school $5^{\text {th }}$ grade students, at the same time, it was the first school year that the teachers responsible for the proper implementation of the program applied this program in class. It can be said that the scale development process is carried out with a sample of limited number of students considering the difficulties experienced by the researchers in reaching the students and the teachers who fully implement the renewed curriculum. From this point of view, new scales can be developed in different sample groups and at different times within the framework of future studies, and it can contribute to the literature in order to evaluate the curriculum effectively. In the future studies, the students' opinions about the evaluation of the 2017 ITS course curriculum of the school $5^{\text {th }}$ grade students can be analyzed in terms of different variables in a broader perspective and high-level quantitative and qualitative research can be patterned by using the "2017 ITS Course Curriculum Evaluation Student Scale". In addition, with the implementation of the required validity and reliability studies, "2017 ITS Course Curriculum Evaluation Student Scale" can also be used to get $6^{\text {th }}$ grade students' opinions in the evaluation of the curriculum since the secondary school ITS course curriculum involves performing the same units at different grade levels and implementation and evaluation process in accordance with a higher-grade acquisitions.

\section{REFERENCES}

Akbıyık, C., \& Seferoğlu, S.S. (2012). Instructing ICT lessons in primary schools: teachers' opinions and applications. Educational Sciences: Theory \& Practice, 12(1), 401-424.

Aközbek, A. (2008). The evaluation of 9th grade mathematic curriculum via the opinions of teachers and students by using context, input, process and product (Cipp) model (general high schools, vocational and technical high schools) (Unpublished master thesis). Yildiz Technical University, Istanbul.

Barut, E., \& Kuzu, A. (2017). The comparison of Turkey and UK's information technologies curriculum in the context of objectives, acquisition, activities, measurement and evaluation. Trakya University Journal of Faculty of Education, 7(2), 721-745.

Bilişim Teknolojileri Eğitimcileri [BTE] Derneği [Association of ICT Educators]. (2017). Bilişim teknolojileri ve yazılım dersi taslak öğretim programının değerlendirilmesi [Evalulation of draft curriculum of information technologies and software course], Retrieved from www.bte.org.tr. 
Brown, T. A. (2006). Confirmatory factor analysis for applied research. New York, NY: Guilford.

Büyüköztürk, Ş. (2010). Sosyal bilimler için veri analizi el kitabı [Handbook of data analysis for social sciences]. Ankara: Pegem Akademi.

Byrne, B. M. (1998). Structural equation modeling with lisrel, prelis and simlis: Basic concepts, applications and programming. Mahwah, NJ: Lawrence Erlbaum Associates.

Catell, R. B. (1978). The scientific use of factor analysis. New York: Plenum.

Comrey, A., \& Lee, H. (1992). A first course in factor analysis. Hillsdale, NY: Erlbaum.

Çelebi Uzgur, B., \& Aykaç, N. (2016). The evaluation of information technologies and software course's curriculum according to the teacher's ideas. Mustafa Kemal University Journal of Social Sciences Institute, 13(34), 273-297.

Çengel, M. (2007). Curriculum evaluation of elementary school fourth grade's computer and information Technologies course (Unpublished master thesis). Adnan Menderes University, Aydin.

Çokluk, Ö., Şekercioğlu, G., \& Büyüköztürk, Ş. (2012). Sosyal bilimler için çok değişkenli istatistik: SPSS ve LISREL uygulamaları [Multivariate statistics for social sciences: SPSS and LISREL practices]. Ankara: Pegem Akademi.

Demirer, V., \& Sak, N. (2015). Information and communication technology (ICT) education in Turkey and changing roles of the ICT teachers. The Journal of International Educational Science, 2(5), 434-448.

Demirtaş, Z. (2017). A general view to program evaluation approaches in education. Sakarya University Journal of Education, 7(4-Special issue), 756-768.

Erçetin, Ş. Ş., \& Durak, A. (2017). Processing, problems and solution suggestions of information technologies and software course in middle schools: Teacher opinions. Bartin University Journal of Faculty of Education, 6(1), 159-176.

European Parliament and the Council of Europe. (2008). Recommendation of the European Parliament and of the Council of 23 April 2008 on the establishment of the European Qualifications Framework for lifelong learning. Official Journal of European Union, 2008/C(C111/01), 1-8. Retrieved from https://www.myk.gov.tr/images/articles/ AYC/pdf/AYCTavsiyeKarar.pdf.

Fernandez, G. (2011). Statistical data mining using SAS applications. Buca Raton, FL: CRC Press.

Fırat Durdukoca, Ş., \& Arıbaş, S. (2011). The evaluation of the optional information technologies lesson 5th curriculum in primary education according to teachers' views (the case of Malatya). Yuzuncu Yil University Journal of Faculty of Education, 8(1), 140-168.

Field, A. (2009). Discovering statistics using SPSS. London: Sage 
Gorsuch, R. L. (1983). Factor analysis. Hillsdale, NJ: Erlbaum

Gravetter, J. F. \& Forzano, L. B. (2012). Research methods for the behavioral sciences. USA: Linda Schreiber-Ganster.

Gülbahar, Y. \& Kalelioğlu, F. (2018). Information and communication technologies and computer science: the process of curriculum development., Milli Eğitim Dergisi, 217, 123.

Gülcü, A., Aydın, S., \& Aydın, Ş. (2013). Evaluation of the new teaching programme developed under the name of svet in informatics technologies lesson in the vocational high schools via the teachers' point of view. Giresun University the Black Sea Journal of Social Sciences, 5(8), 73-92.

Gündüz, G. F., \& Kuzu Demir, E. B. (2018). Comparison of $20175^{\text {th }}$ grade information technologies and software course draft curriculum and 2012 information technologies and software course curriculum. Turkish Online Journal of Qualitative Inquiry, 9(2), 147-175.

Hooper, D., Coughlan, J., \& Mullen M. (2008). Structural equation modelling: guidelines for determining model fit. Electronic Journal of Business Research Methods 6(1), 53-60.

Kabakçı, I., Kurt, A., \& Yıldırım, Y. (2008). Bilgisayar öğretmenlerinin seçmeli bilişim teknolojileri öğretim programının uygunluğuna ilişkin görüşlerinin belirlenmesi. In A. Kuzu (Eds.), Proceedings of VIII. International Educational Technology Conference, (pp.518-526). Eskişehir: Anadolu Üniversitesi.

Karaman, G., \& Karaman, U. (2019). Comparison of informatics technologies and software development course curricula in 2012 and 2017. Kastamonu Education Journal, 27(1), 309-318.

Karal, H. Reisoğlu, İ., \& Günaydın, E. (2010). İlköğretim bilişim teknolojileri dersi öğretim programının değerlendirilmesi. Çukurova University Journal of Faculty of Education, 38 (1), 46-64.

Kass, R. A., \& Tinsley, H. E. A. (1979). Factor analysis. Journal of Leisure Research, $11,120-138$.

Kline, R. B. (2015). Principles and practice of structural equation modeling. New York, NY: Guilford.

Kocabatmaz, H. (2011). The evaluation of the technology and design curriculum (Unpublished master thesis). Ankara University, Ankara.

Kural Er, F., \& Güven, B. (2008). Perceptions of teachers toward primary school 6, 7, and 8th grade computer course content. Manas Journal of Social Studies, 19, 175-184.

Mercimek, B., \& İliç, U. (2017). An evaluation for update suggestion of information technologies and software course curriculum. Academia Journal of Educational Research, 2(1), 1-9. 
MNE (Ministry of National Education). (2017a). Bilişim teknolojileri ve yazılım dersi taslak ögretim programı (Ortaokul 5. ve 6. sinıflar). [Computer science and software draft curriculum (Secondary school 5th and 6th grades)]. Ankara: Milli Eğitim Bakanlığ1 Yayınevi. Retrieved from http://mufredat.meb.gov.tr/Dosyalar/ 2018124103559587-Bili\%C5\%9Fim\%20Teknolojileri\%20ve\%20Yaz\%C4\%B11\%C4 \%B1m\%205-6.\%20S\%C4\%B1n\%C4\% B1flar.pdf.

MNE. (2017b). Ortaokul ve İmam Hatip Ortaokulu bilişim teknolojileri ve yazılım dersi (5 ve 6. Sinıflar) öğretim programı [Curriculum of computer technologies and software course at secondary and İmam Hatip secondary schools (5th and 6th grades)]. MEB Tebliğler Dergisi, $2718(80), 1616$.

Özbey, N., \& Küçükoğlu, A. (2018). The comparison of curriculum regarding information technologies in England, Australia and Turkey. International Journal of Innovative Approaches in Education, 2(3), 76-109. doi: 10.29329/ijiape.2018.177.2.

Özdamar, K. (2002). Paket programlar ile istatistiksel veri analizi [Statistical data analysis with packaged software]. Eskişehir: Kaan Yayınları.

Pallant, J. (2026). SPSS survival manual: A Step by step guide to data analysis using SPSS program. New York, NY: Open University Press.

Raykov, T., \& Marcoulides, G. A. (2006). A first course in structural equation modeling. Mahwah, NJ: Lawrence Erlbaum Associates.

Seferoğlu, S. S. (2007). Primary school computer curriculum: A critical evaluation and problems faced during implementation. Eurasian Journal of Educational Research, 29, 99-111.

Sert, Ö. (2007). Application of the modular training systems in information technologies area and evaluation of these systems via the teachers and the students in the secondary VET institutions (Unpublished master thesis). Marmara University, İstanbul.

Sümer, N. (2000). Structural equation modelling: basic concepts and applications. Turkish Psychological Review, 3(6),49-74.

Şimşek, F.Ö. (2007). Yapısal eşitlik modellemesine giriş: temel ilkeler ve LISREL uygulamalarl [Introduction to structural equation modeling: basic principles and LISREL practices]. Ankara: Ekinoks.

Tabachnick, B. G., \& Fidell, L. S. (2013). Using multivariate statistics. New York, NY: Harper \& Row.

Tanataş, D. (2010). Teacher opinions about application of the optional information technologies course teaching program in primary education (The example of Malatya) (Unpublished master thesis). Inonu University, Malatya.

Thompson, B. (2004). Exploratory and confirmatory factor analysis: Understanding concepts and applications. Washington, DC: American Psychology Association. 
Ural, A., \& Kılıç, İ. (2013). Bilimsel araştırma süreci ve SPSS ile veri analizi [Scientific research process and data analysis through SPSS. Ankara: Detay Yayınc1lık.

Uzgur, B. Ç., \& Aykaç, N. (2016). The evaluation of information technologies and software course's curriculum according to the teacher's ideas. Mustafa Kemal University Journal of Social Sciences Institute, 13(34), 273-297.

Vocational Qualifications Institution (VQI). (2015). Türkiye yeterlilikler çerçevesi [Turkey qualifications framework]. Retrieved from http://www.resmigazete.gov.tr/ eskiler/2016/01/20160102-3-1.pdf.

Worthington, R. L., \& Whittaker, T. A. (2006). Scale development research: A content analysis and recommendations for best practices. The Counseling Psychologist, 34, 806838. 